\title{
Efficacy of long-term low-dose sulodexide in diabetic and non-diabetic nephropathies
}

\author{
DIANA-SILVIA ZILIŞTEANU ${ }^{1,2}$, TEODORA ATASIE $^{1}$, M. VOICULESCU ${ }^{1,2}$ \\ ${ }^{1}$ Center of Internal Medicine and Nephrology, Fundeni Clinical Institute, Bucharest \\ 2"Carol Davila" University of Medicine and Pharmacy, Bucharest
}

\begin{abstract}
Background and Aims. Sulodexide has been reported to have antiproteinuric and nephroprotective properties. We investigated the effects of long-term low-dose Sulodexide on proteinuria and renal function in patients with chronic kidney disease (CKD) caused by diabetic nephropathy (DN), hypertensive nephropathy $(\mathrm{HN})$ and primary glomerulonephritis (GN).

Material and Methods. 100 patients with CKD received low-dose Sulodexide $50 \mathrm{mg} /$ day for 12 months. Treatment efficacy was evaluated as proteinuria reduction compared to baseline; response was defined as a decline in proteinuria below $0.3 \mathrm{~g} / \mathrm{d}$. Renal function evolution was assessed by eGFR variation from baseline.

Results. All patients presented reduction of proteinuria, with global mean value of proteinuria decrease of $0.85 \pm 1.34 \mathrm{~g} / \mathrm{d}(\mathrm{p}<0.0001)$. Patients with $\mathrm{HN}$ had the highest mean percentage of proteinuria reduction $(73 \pm 29 \%)$ and the lowest mean time period to achieve responder status $(6.6 \pm$

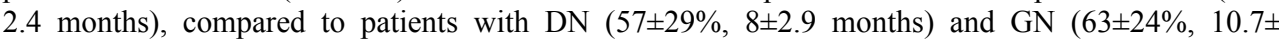
1.2 months). Renal function as mean eGFR remained stable or improved during the study; significant increase was found only in $\mathrm{HN}$ group $\left(3.41 \pm 6.38 \mathrm{ml} / \mathrm{min} / 1.73 \mathrm{~m}^{2}, \mathrm{p}=0.043\right)$. Multivariate regression analysis identified that responder status was significantly associated with gender, baseline eGFR, baseline proteinuria and etiology of CKD. Concomitant administration of ACEIs or/and ARBs did not influence the response to Sulodexide therapy.

Conclusions. Independently of ACEIs or/and ARBs therapy, long-term low-dose Sulodexide is efficient as antiproteinuric and renoprotective therapy in patients with CKD caused by DN, GN and HN. Better response is achieved in patients with lower degree of renal dysfunction.
\end{abstract}

Key words: sulodexide, nephropathy, proteinuria, renal function, CKD progression.

\section{BACKGROUND AND AIMS}

During the last decades, developing of safe and effective kidney-protective interventions to slow or stop the progression of established nephropathy is an important strategy in reducing the incidence of end stage renal disease. Thus, it is to be understood why many studies have focused on the investigation of molecules that could contribute to reducing proteinuria and to slowdown the progression of chronic kidney disease. Significant steps in this direction were made by introducing angiotensin-converting enzyme inhibitors (ACEIs) in 1993 and angiotensin receptor blockers (ARBs) in 2001, while other molecules like glycosaminoglycans (GAGs), despite promising data in experimental studies, are still gathering evidence of clinical applicability [1].

Sulodexide (Vessel Due F, Alfa Wassermann S.p.A Bologna, Italy) is a natural structure, extract from mammalian intestinal mucosa, with a complex architecture including a highly purified mixture of GAGs, consisting in a fast moving heparin-like fraction: iduronilglucosaminilglycan sulphate $(80 \%)$ and dermatan sulphate (20\%); compared to standard heparin, sulodexide has a longer half-life, high oral bioavailability and reduced effect on systemic clotting and bleeding [2]. Sulodexide has proved beneficial cardiovascular effects explained by several pharmacological actions: (1) antithrombotic activity mainly through inhibition of intrinsic factor $\mathrm{Xa}$ activation (Sulodexide is the second most effective inhibitor of intrinsic factor Xa activation!) and accelerating the inhibition of thrombin by interacting with antithrombin III and heparin cofactor II; (2) fibrinolysis activation by increase of tissue plasminogen activator activity and by decrease of plasminogenic activator inhibitor-1; (3) tissue perfusion facilitation by prevention of vascular inflammatory injuries, possibly through the inhibition of complement activation and inhibition of C-reactive protein; (4) antilipemic and antiatherosclerotic effects by lipoprotein lipase release; (5) restoration of venous wall tonicity, via reduction/ inhibition of matrix metalloproteinases MMP-9 forms from leukocytes/platelets and inhibition of 
type IV collagen degradation; (6) restoration of vascular permeability by increase of the thickness of endothelial glycocalyx; (7) improvement of endothelium-dependent relaxation in arteries [3-6].

Moreover, experimental and clinical studies identified several mechanisms of action which can explain its potential benefit in renal diseases. Thus, Sulodexide has the capacity to replace lost endogenous heparan sulphate (HS) and to restore the anionic charges, both at vascular endothelial and glomerular cells levels. Restoration of HS in mesangial cells inhibits their proliferation, [7] and in podocytes contributes to restoration of glomerular basement membrane (GBM) permeability to albumin [8]. At extracellular level, Sulodexide precludes the extracellular matrix expansion and type III and type IV collagen deposition, by inhibition of the expression and bioactivity of transforming growth factor TGF- $\beta 1$ [9]. Also, Sulodexide has the capacity to inhibit heparanase-1, preventing epithelial-mesenchymal transition and renal interstitial fibrosis induced via FGF-2 loop [10]. Therefore, preclinical and clinical evidence support the antiproteinuric and nephroprotective effects of GAGs and Sulodexide, justifying their administration not only in DN, but also in other chronic nephropathies [11].

The aim of our study was to evaluate the efficacy of Sulodexide in different chronic nephropathies accompanied by proteinuria. We assessed Sulodexide capacity to contribute to a decrease in proteinuria, while preserving/improving the level of glomerular filtration rate.

\section{MATERIAL AND METHODS}

\section{STUDY PATIENTS}

We performed a prospective study in patients over 18 years with CKD caused by diabetes mellitus, primary hypertension or primary glomerulonephritis, hospitalized in our center between January 2010 and July 2012, and in whom treatment with oral Sulodexide (Vessel Due F) was started as decided by each patient's attending physician. Data were collected prospectively from the medical records of patients: demographics (age, gender), etiology of renal disease (diabetic nephropathy, hypertensive nephropathy and glomerular nephropathy), history of antihypertensive treatment (angiotensin converting enzyme inhibitors [ACEI], angiotensin receptor blockers [ARB], beta blockers, calcium channel blockers), clinical data (body mass index, systolic and diastolic blood pressure, heart rate) and laboratory parameters (serum creatinine, serum albumin, glycaemia, serum cholesterol and triglycerides, proteinuria; estimated GFR [eGFR] was calculated using the Chronic Kidney Disease Epidemiology Collaboration formula). Clinical and biological parameters were also recorded after 12 months of treatment with Sulodexide.

\section{TREATMENT EFFICACY}

Low-dose of $50 \mathrm{mg} /$ day Sulodexide was administered daily in all patients for 12 months. Patients with diabetes mellitus were under specific medication in order to control the glucose blood level and arterial blood pressure as decided by their physician; none of the patients with primary GN was on immunosuppressive therapy. During their long-term treatment (12 months) with Sulodexide, patients did not change their diet or the antidiabetic and antihypertensive therapy.

The primary indicator was the evolution of proteinuria after 12 months of treatment. Efficacy was calculated as proteinuria variation from baseline to the end of study, and evaluated in the study group and in subgroups by considering patients as responders or non-responders. Response was defined as a decline in proteinuria below $0.3 \mathrm{~g} /$ day. Time to response was defined as the treatment duration until a patient achieved the responder status. Additionally, the renal function evolution was evaluated as eGFR at the end of the study compared to baseline.

\section{STATISTICAL ANALYSIS}

Data were analyzed using the software package SPSS for Windows release 21. Baseline characteristics of groups were compared using independent samples t test, ANOVA and chi-squared test (for categorical data) and Mann-Whitney $U$ test for non-parametrical data. A $\mathrm{p}$ value $<0.05,95 \% \mathrm{CI}$ was considered statistically significant. We applied logarithmic transformation for proteinuria in order to improve the normal data distribution.

Paired-Samples T Test was used to determine whether there is a statistically significant difference between the pre- and post-treatment levels of proteinuria within study patients.

ANOVA and Bonferroni test for multiple comparisons were used to evaluate the percent reductions in baseline proteinuria at 12 months in each CKD group. As described by Gambaro et al. [12], the percent reduction in proteinuria was calculated as

$$
\% \text { reduction }=1-\exp (\Delta)
$$


where $\Delta$ is the difference in adjusted mean $\ln$ (proteinuria) at baseline and after 12 months of treatment with Vessel Due F.

Unadjusted response rates were studied using the Kaplan-Meier survival analysis based on logrank test. Cox regression analysis applying backward stepwise method was used to build a time-toresponse model adjusted for different explanatory variables.

\section{RESULTS}

A total of 100 patients were included in this analysis. The etiology of renal disease was DN in
58 patients $(58 \%)$, GN in 25 patients $(25 \%)$ and $\mathrm{HN}$ in 17 patients $(17 \%)$.

Mean age was significantly lower in GN patients ( $44 \pm 13$ years) compared to diabetic $(59 \pm$ 11 years) and hypertensive (66 \pm 6 years) patients, while all the other baseline demographic, clinical and biological parameters were similar between groups (Table 1).

There were included patients with CKD stage $1-4\left(\right.$ eGFR $\left.>15 \mathrm{ml} / \mathrm{min} / 1.73 \mathrm{~m}^{2}\right)$; the distribution between CKD stages was similar between the study groups. All patients presented baseline proteinuria above $0.3 \mathrm{~g} /$ day; nephrotic range proteinuria was present only in $3.4 \%$ diabetic patients and in $4 \%$ patients with glomerulonephritis (Table 2).

Table 1

Baseline characteristics of the study patients

\begin{tabular}{|c|c|c|c|c|}
\hline & $\begin{array}{l}\text { Diabetic nephropathy } \\
\qquad(\mathrm{n}=61)\end{array}$ & $\begin{array}{l}\text { Glomerulonephritis } \\
\quad(\mathrm{n}=\mathbf{2 6})\end{array}$ & $\begin{array}{c}\text { Hypertensive } \\
\text { nephropathy } \\
(n=17) \\
\end{array}$ & $p$ \\
\hline Mean age & $59 \pm 12$ & $44 \pm 16$ & $66 \pm 6$ & $<0.05$ \\
\hline Gender (male, \%) & 62.1 & 68 & 41 & NS \\
\hline BMI & $27 \pm 5$ & $26 \pm 4$ & $26 \pm 6$ & NS \\
\hline Serum creatinine $(\mathrm{mg} / \mathrm{dl})$ & $1.6 \pm 0.7$ & $1.7 \pm 1.0$ & $1.5 \pm 0.6$ & NS \\
\hline $\mathrm{eGFR}\left(\mathrm{ml} / \mathrm{min} / 1.73 \mathrm{~m}^{2}\right)$ & $50 \pm 20.3$ & $54.9 \pm 27.7$ & $49.8 \pm 21.7$ & NS \\
\hline Glycaemia (mg/dl) & $108 \pm 24$ & $93 \pm 20$ & $104 \pm 21$ & NS \\
\hline Cholesterol (mg/dl) & $213 \pm 43$ & $230 \pm 33$ & $226 \pm 34$ & NS \\
\hline Triglycerides (mg/dl) & $169 \pm 21$ & $158 \pm 28$ & $150 \pm 22$ & NS \\
\hline Serum albumin $(\mathrm{g} / \mathrm{dl})$ & $3.9 \pm 0.4$ & $3.8 \pm 0.4$ & $3.9 \pm 0.3$ & NS \\
\hline Proteinuria (g/day) & $1.5 \pm 1.8$ & $1.9 \pm 1.8$ & $0.7 \pm 0.3$ & NS \\
\hline Hypertension (yes, \%) & $86.1 \%$ & $68 \%$ & $100 \%$ & NS \\
\hline SBP (mmHg, mean) & $145 \pm 14$ & $144 \pm 14$ & $144 \pm 16$ & NS \\
\hline DBP (mmHg, mean) & $78.5 \pm 8.1$ & $76.9 \pm 6.2$ & $77.6+6.6$ & NS \\
\hline HR (beats/min, mean) & $71 \pm 6$ & $74 \pm 12$ & $75 \pm 15$ & NS \\
\hline ACEI (yes, \%) & 37 & 36 & 50 & NS \\
\hline ARBs (yes, \%) & 48.1 & 60 & 43 & NS \\
\hline ACEI + ARBs (yes, \%) & 18.5 & 28 & 25 & NS \\
\hline Beta blockers (yes, \%) & 35.2 & 24 & 50 & NS \\
\hline Calcium blockers (yes, \%) & 37 & 16 & 50 & NS \\
\hline
\end{tabular}

Values are mean \pm SD or absolute numbers.

Table 2

Baseline distribution of eGFR and proteinuria categories, stratified by CKD etiology

\begin{tabular}{lccccc}
\hline & & Diabetic nephropathy & Glomerulonephritis & $\begin{array}{c}\text { Hypertensive } \\
\text { nephropathy }\end{array}$ & $\boldsymbol{p}$ \\
\hline \multirow{5}{*}{ Baseline eGFR } & $>=90 \mathrm{ml} / \mathrm{min} / 1.73 \mathrm{~m}^{2}$ & $0 \%$ & $12 \%$ & $0 \%$ & $\mathrm{NS}$ \\
& $60-89 \mathrm{ml} / \mathrm{min} / 1.73 \mathrm{~m}^{2}$ & $31 \%$ & $32 \%$ & $41.2 \%$ & $\mathrm{NS}$ \\
& $30-59 \mathrm{ml} / \mathrm{min} / 1.73 \mathrm{~m}^{2}$ & $51.7 \%$ & $32 \%$ & $35.3 \%$ & $\mathrm{NS}$ \\
\hline \multirow{3}{*}{ Baseline proteinuria } & $15-29 \mathrm{ml} / \mathrm{min} / 1.73 \mathrm{~m}^{2}$ & $17.2 \%$ & $24 \%$ & $23.5 \%$ & $\mathrm{NS}$ \\
& $<15 \mathrm{ml} / \mathrm{min} / 1.73 \mathrm{~m}^{2}$ & $0 \%$ & $0 \%$ & $0 \%$ & $\mathrm{NS}$ \\
\hline
\end{tabular}

After one year of active treatment, all patients presented reduction of proteinuria, while renal function remained stable or even increased (Figure 1).
The highest percent of proteinuria reduction compared to baseline was observed in $\mathrm{HN}$ group $(73 \pm 29 \%)$, while patients with DN and GN had 
almost similar percent $(57 \pm 29 \%$, respectively $63 \pm$ $24 \%$ ). As regards the evolution of renal function, mean eGFR presented a slight increase in patients with diabetes mellitus $\left(0.48 \pm 8 \mathrm{ml} / \mathrm{min} / 1.73 \mathrm{~m}^{2}\right.$, $\mathrm{p}=0.647)$ and $\mathrm{GN}\left(4.16 \pm 18.97 \mathrm{ml} / \mathrm{min} / 1.73 \mathrm{~m}^{2}\right.$, $\mathrm{p}=0.284$ ), and a significant one in patients with $\mathrm{HN}$ $\left(3.41 \pm 6.38 \mathrm{ml} / \mathrm{min} / 1.73 \mathrm{~m}^{2}, \mathrm{p}=0.043\right)$. Looking for eGFR evolution stratified by baseline CKD stage, we found stable renal function in stage $2(-0.36 \pm$ $\left.11.78 \mathrm{ml} / \mathrm{min} / 1.73 \mathrm{~m}^{2}, \mathrm{p}=0.86\right) v s$. significant increase in stage $3\left(3.32 \pm 6.82 \mathrm{ml} / \mathrm{min} / 1.73 \mathrm{~m}^{2}, \mathrm{p}=0.003\right)$ and an important increase in stage $4(6.55 \pm 14.71$ $\mathrm{ml} / \mathrm{min} / 1.73 \mathrm{~m}^{2}, \mathrm{p}=0.061$ ).

The overall mean value of proteinuria significantly decreased by $0.85 \pm 1.34 \mathrm{~g} / \mathrm{d}$ $(\mathrm{p}<0.0001,95 \%$ CI $0.58-1.11)$ with a Pearson correlation coefficient of 0.649 . Subgroup analysis showed the highest correlation of proteinuria reduction in patients with $\mathrm{DN}$ and $\mathrm{HN}$ (Table 3).

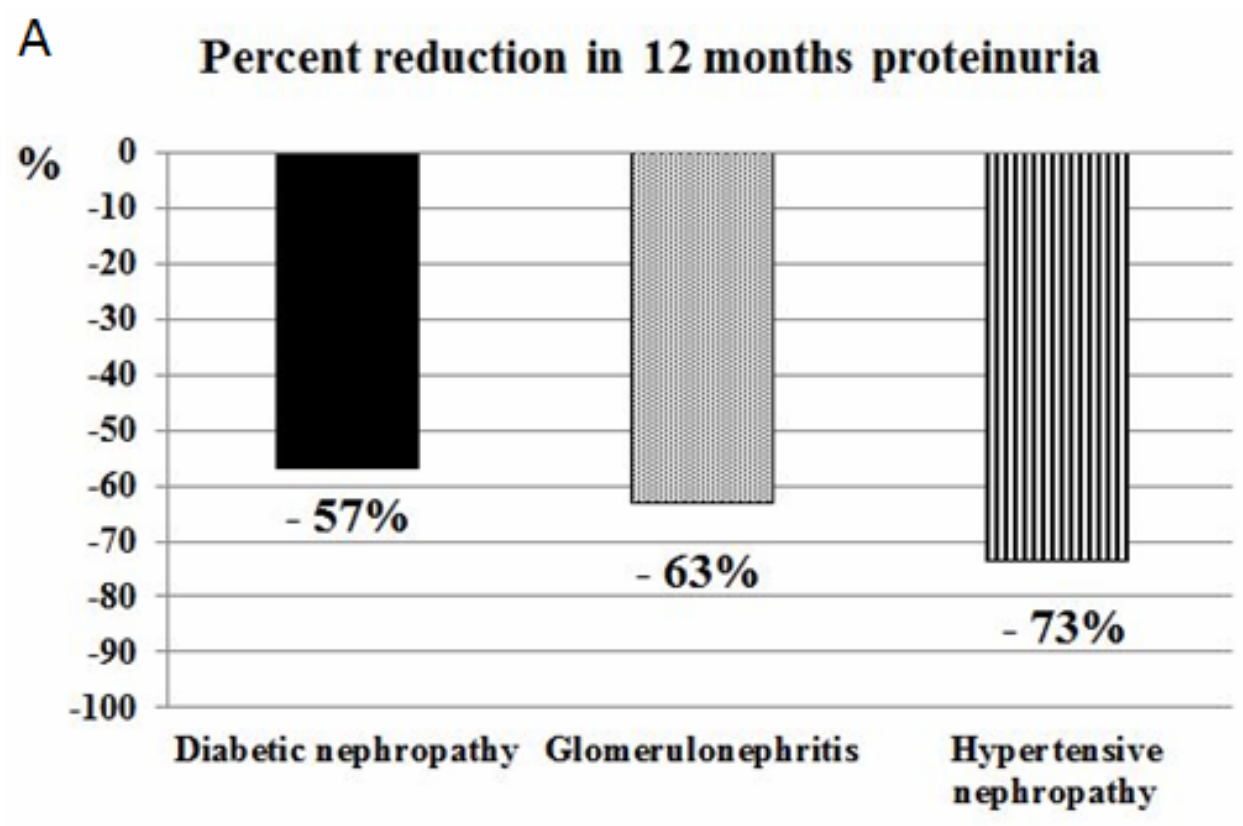

B

Mean eGFR at baseline and after 12 months

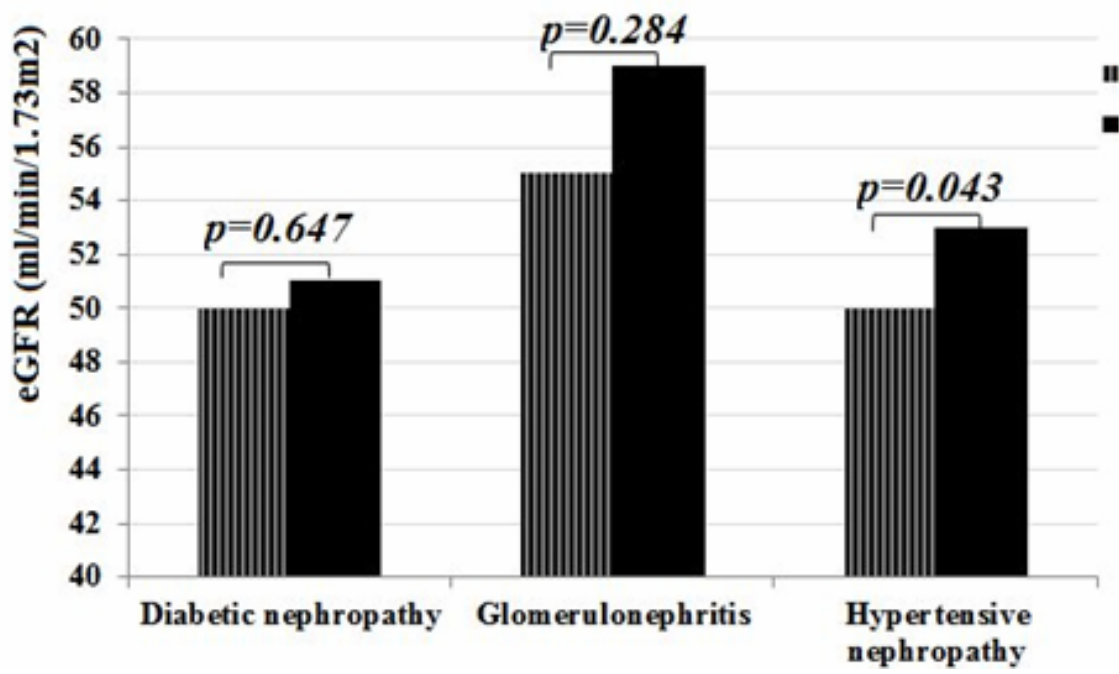

Fig. 1. Evolution in proteinuria (1a) and renal function (1b) after 12 months of treatment, stratified by etiology of renal disease. 
Table 3

Average difference between proteinuria before the treatment and after 12 months of treatment, stratified by the etiology of renal disease

\begin{tabular}{llccc}
\hline & \multicolumn{1}{c}{$\begin{array}{c}\text { Mean reduction } \\
\text { in proteinuria }\end{array}$} & $95 \%$ CI & $\begin{array}{c}\text { Pearson } \\
\text { coefficient }\end{array}$ & $p$ \\
\hline Diabetic nephropathy & $0.77 \pm 1.3$ & $0.42-1.11$ & 0.758 & $<0.0001$ \\
Glomerulonephritis & $1.29 \pm 1.76$ & $0.56-2.01$ & 0.283 & 0.001 \\
Hypertensive nephropathy & $0.48 \pm 0.23$ & $0.37-0.59$ & 0.691 & $<0.0001$ \\
\hline
\end{tabular}

Global rate of response was $47 \%$. Percent of responders was significantly higher $(p<0.05)$ in the HN group (70.6\%) compared to DN group (43.1\%) and GN group (40\%). Also, percentage of responders was higher as initial renal kidney function was better: $66.7 \%$ in CKD stage $1,63.6 \%$ in CKD stage 2 vs $45.5 \%$ in CKD stage 3 and $25 \%$ in in CKD stage $4(p<0.05)$. In our study group, none of the patients with nephrotic range proteinuria at baseline (3.4\% from the total patients with $\mathrm{DN}$ and $4 \%$ from the total patients with GN) was able to achieve responder status (proteinuria decrease $<0.3 \mathrm{~g} / \mathrm{d}$ ) at the end of study (data not shown).
Mean time to achieve responder status was $8.2 \pm 2.8$ months. Unadjusted analysis showed a significant difference $(p=0.008)$ between groups stratified by etiology of renal disease (Figure 2). In patients with $\mathrm{HN}$ it was noted the shortest time to response (6.6 \pm 2.4 months) compared to patients with $\mathrm{DN}(8 \pm 2.9$ months $)$ and GN $(10.7 \pm 1.2$ months).

When analysed according to the baseline eGFR, a faster achievement of responder status was noted in patients with better renal function at the beginning of treatment, with significant difference $(p=0.004)$ between different stages of CKD (Figure 3 ).

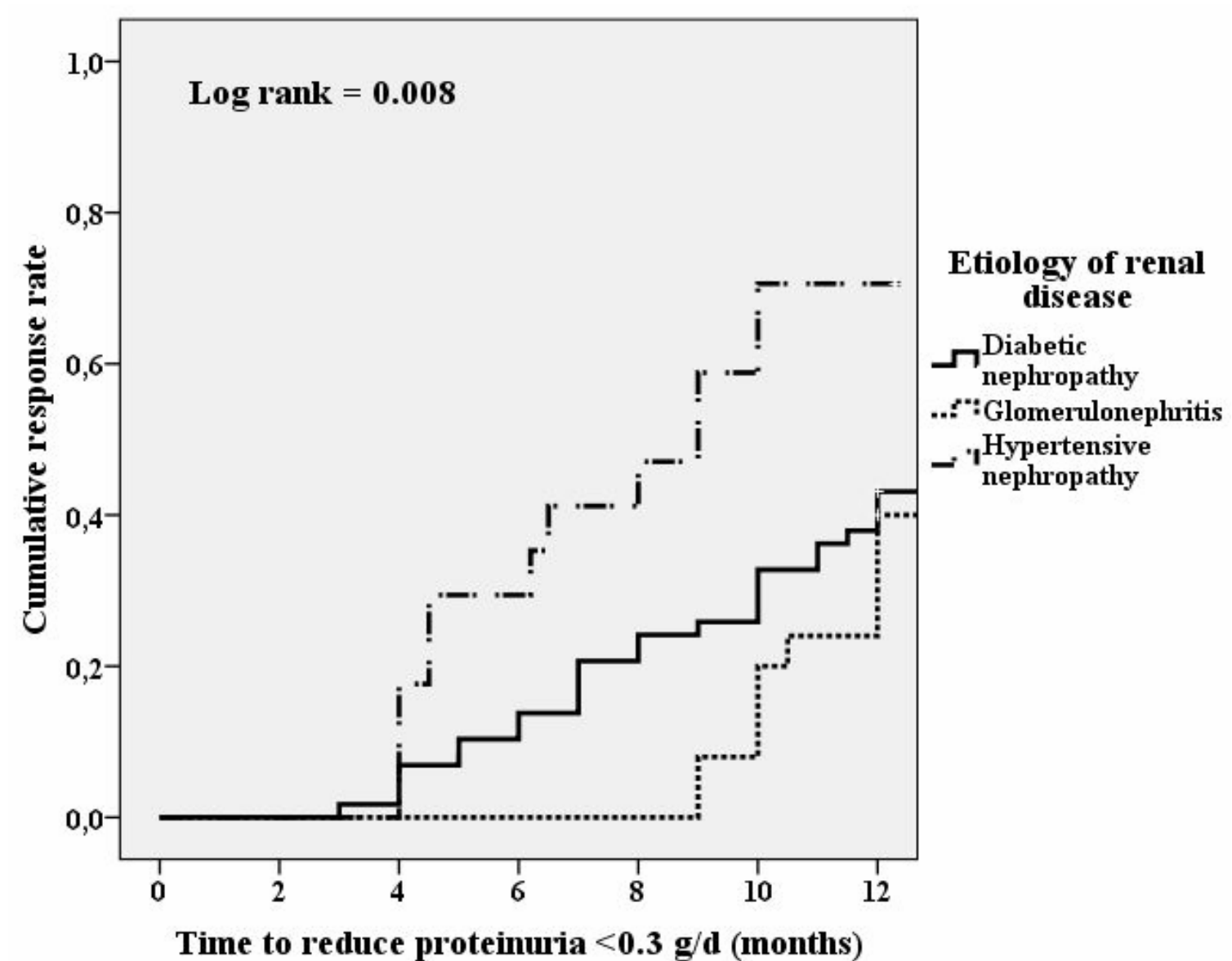

Fig. 2. Cumulative response rate stratified by etiology of renal disease (unadjusted analysis). 


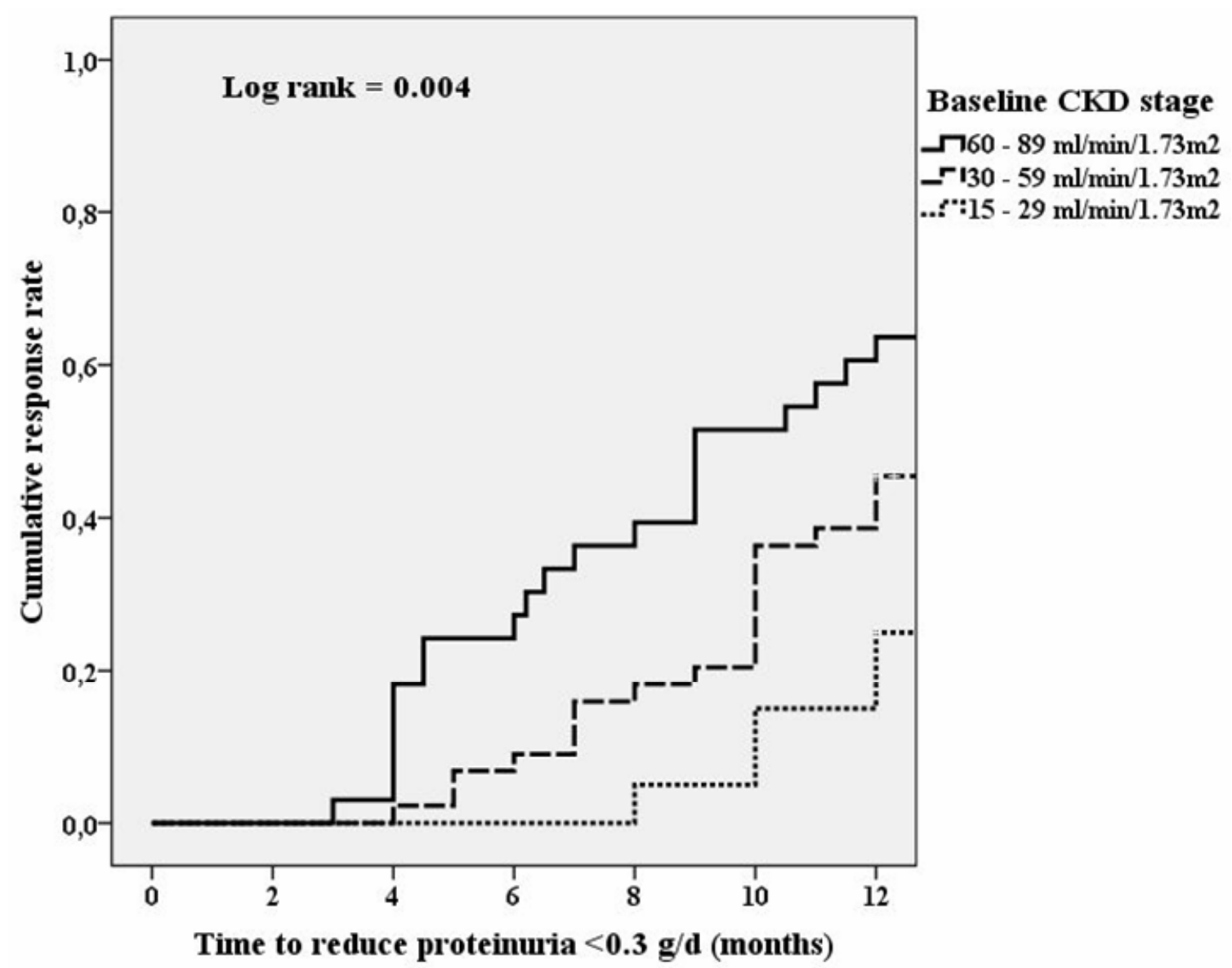

Figure 3. Cumulative response rate according to baseline CKD stage (unadjusted analysis).

Multivariate regression analysis identified that responder status was significantly associated with male gender, baseline eGFR, baseline proteinuria, and etiology of renal disease (Table 4). Thus, the response hazard for a male is 3.948 times that of a female patient.

Also, diabetic patients have 0.445 response hazard compared to hypertensive nephropathy $(\mathrm{p}=0.015)$, and patients with glomerulonephritis is
0.377 of those with hypertensive nephropathy $(p=0.047)$. Considering the impact of baseline renal function, taking CKD stage 4 as reference range, the response hazard is 3.014 times higher for a patient with CKD stage 2, and 1.688 times higher for a patient with CKD stage 3. As regards the influence of baseline proteinuria, the response hazard decreases with $60.7 \%$ for 1 gram increase in daily urinary protein loss.

Table 4

Multivariate Cox regression model for achievement of responder status

\begin{tabular}{l|c|c|c}
\hline & Exp(B) & $95 \%$ CI for $\operatorname{Exp}(\mathrm{B})$ & $p$ \\
\hline Gender (female $=$ reference) & 3.948 & $1.619-6.635$ & 0.001 \\
\hline Baseline proteinuria & 0.393 & $0.105-0.519$ & $<0.0001$ \\
\hline Baseline eGFR (CKD stage 4 reference) & & & \\
CKD stage 2 & 3.014 & $1.004-9.077$ & 0.045 \\
CKD stage 3 & 1.688 & $0.588-4.846$ & 0.05 \\
\hline Etiology of renal disease (HTN = reference) & & \\
Diabetic nephropathy & 0.445 & $0.110-0.914$ & $\mathrm{p}=0.015$ \\
Glomerulonephritis & 0.377 & $0.105-0.519$ & $\mathrm{p}=0.047$ \\
\hline
\end{tabular}

We also analysed the influence of ACEIs and/or ARBs treatment on the response rate and time to achieve responder status. We found no difference $(p=0.836)$ between response rate and mean time to achieve the responder status between subgroups of patients with/without therapy acting on the RAA system (data not shown). Also, in multivariate analysis, treatment with ACEIs and/or ARBs was not found as factor that significantly influences the proteinuria reduction. 


\section{DISCUSSION}

Our study showed that 12 months treatment with low-dose Sulodexide (50 mg/day) significantly reduced proteinuria in patients with $\mathrm{CKD}$ caused by diabetes mellitus, primary GN and HN. Mean global decrease of proteinuria level was $0.85 \pm$ $1.34 \mathrm{~g} /$ day $(\mathrm{p}<0.0001)$, and almost half of our patients achieved responder status (final proteinuria dropped below $0.3 \mathrm{~g} /$ day). As glomerular filtration rate remained stable or even increased, proteinuria reduction cannot be explained by alteration of filtration capacity. Of notice, better response was achieved in patients with better renal function at baseline.

More than half of our patients had DN, which was the most studied medical condition in which Sulodexide was used. A large number of studies advocated the potential role of Sulodexide as an antiproteinuric agent in type 1 and 2 diabetes patients [11]. Since 20 years ago, Solini et al. investigated the anti-albuminuric role of Sulodexide in clinical DN [12]. In DiNAS trial, Gambaro et al. demonstrated that a 4 months course of oral Sulodexide can significantly improve either micro- or macroalbuminuria in both type 1 and type 2 diabetes mellitus, with approximately linear dose-response [13]. Maximum dose (200 $\mathrm{mg} /$ day) induced the highest reduction in albuminuria, effect which was sustained even after treatment cessation. More recently, DAVET study presented evidence for the efficacy of low-dose $50 \mathrm{mg} /$ day Sulodexide, which was able to induce significant reduction in albuminuria when continued therapy over 12 months [14]. Likewise, our results were obtained after long-term administration of low-dose of Sulodexide.

A quarter of our patients had primary GN as cause of CKD. In this patient category, we also found significant results after Sulodexide therapy: significant proteinuria reduction (mean percentage $63 \pm 24 \%)$ and slight increase in eGFR $(4.16 \pm$ $18.97 \mathrm{ml} / \mathrm{min} / 1.73 \mathrm{~m}^{2}$ ), without any immunosuppressive therapy. Until now, only a few studies described use of Sulodexide in non-diabetic nephropathies, with conflicting results. Rozita et al. reported a significant response after 3 and 6 months of Sulodexide as rescue therapy in 16 proteinuric patients with chronic glomerulonephritis unresponsive to conventional therapies [15]. On the other hand, Bang et al. did not find a significant difference between placebo vs Sulodexide $75 \mathrm{mg} /$ day and $150 \mathrm{mg} /$ day administered in patient with $\operatorname{IgA}$ nephropathy, although the highest dose significantly reduced proteinuria [16].
Even fewer clinical data are available on the use of Sulodexide in HN. In our patients, we unexpectedly found the best response in patients with nephroangiosclerosis due to primary hypertension: the highest percent of responders and the lowest time to response. Considering that diabetic and $\mathrm{HN}$ share some similar pathogenic mechanisms leading to proteinuria, like glomerular hyperfiltration and impairment of glomerular charge selectivity $[17,18]$, we can thus explain the benefits of Sulodexide in this patient category.

In our study, we found that the proteinlowering effect was additive to and independent of the concomitant administration of ACEIs or/and ARBs. Similar results were described in diabetic patients from DiNAS study [12], as well as in a pilot study reporting return to normoalbuminuria or a decrease in albumin: creatinine ratio (ACR) of at least $50 \%$ in spite of the maximum recommended dose of an ACEIs or an ARBs [19].

Looking to the starting treatment point when Sulodexide intervention could be more efficient within CKD evolution, we found that earlier administration in the course of disease led to better outcomes. Thus, the percentage of responders progressively decreased as baseline kidney function was more impaired. As shown by experimental studies, Sulodexide has a renal protective role in mitigating glomerular sclerosis and tubulointerstitial fibrosis [19]. Once irreversible histological hallmarks of advanced CKD have been found (namely sclerosis and fibrosis), it is basically impossible to reverse the course of renal failure.

\section{CONCLUSIONS}

Our data show that low-dose long-term (12 months) treatment with Sulodexide is efficient as antiproteinuric therapy in CKD patients. A better response to this long-term low-dose Sulodexide therapy can be achieved in patients with lower degree of renal dysfunction at baseline. Apart from diabetic nephropathy, this treatment approach can induce significant benefits in patients with primary glomerulonephritis and hypertensive nephropathy.

\footnotetext{
Acknowledgements \& Duality of interest

DZ, TA and MV have received honoraria from Alfa Wassermann SpA.

Alfa Wassermann SpA had no role in study design, data collection, data analysis, data interpretation, or writing the report.

The results presented in this article have not been published previously in whole or part, except in abstract format.
} 
Obiectivul studiului. Sulodexid a demonstrat că posedă proprietăți antiproteinurice şi nefroprotectoare, motiv pentru care am decis să investigăm efectele unei doze mici de Sulodexid administrate pe termen lung asupra proteinuriei şi funcției renale la pacienți cu boală cronică de rinchi (BCR) apărută ca urmare a nefropatiei diabetice (ND), hipertensive (NH) sau glomerulonefritelor primare (GN).

Material şi Metodă. 100 de pacienți cu BCR au primit în fiecare zi câte o doză mică de Sulodexid $(50 \mathrm{mg} / \mathrm{zi}$ ) timp de 12 luni. Eficacitatea tratamentului a fost evaluată prin reducerea nivelurilor proteinuriei comparativ cu valorile inițiale; răspunsul terapeutic a fost definit drept o scădere a proteinuriei la valori mai mici de $0.3 \mathrm{~g} / \mathrm{dl}$. Evoluția funcției renale a fost evaluată prin calcularea variației eGFR față de valoarea inițială.

Rezultate. La finalul celor 12 luni de tratament cu Sulodexid, toți pacienții au innregistrat o scădere semnificativă a proteinuriei, cu o valoare globală medie a scăderii proteinuriei de $0.85 \pm 1.34 \mathrm{~g} / \mathrm{dl}(p<0.0001)$. Pacienții cu $\mathrm{NH}$ au inregistrat cea mai ridicată valoare medie procentuală a scăderii proteinuriei (73 $29 \%)$ şi cea mai redusă durată medie a tratamentului până la obținerea răspunsului terapeutic (6.6 2.4 luni), comparativ cu pacienții cu $N D(57 \pm 29 \%$, $8 \pm 2.9$ luni) şi GN $(63 \pm 24 \%, 10.7 \pm 1.2$ luni). Funcția renală ca şi medie eGFR a rămas nemodificată sau s-a ameliorat, o ameliorare semnificativă fiind innregistrată doar in grupul pacienților cu $\mathrm{NH}\left(3.41 \pm 6.38 \mathrm{ml} / \mathrm{min} / 1.73 \mathrm{~m}^{2}, p=0.043\right)$. Analiza regresiei multivariate a identificat că răspunsul terapeutic a fost semnificativ asociat $\mathrm{cu}$ sexul, valorile inițiale ale GFR, proteinuriei şi cu etiologia BCR. Administrarea concomitentă de inhibitori ai enzimei de conversie (IEC) sau/şi blocanți ai receptorilor angiotensinei (BRA) nu au influențat răspunsul terapeutic al administrării de Sulodexid.

Concluzii. Sulodexid în doză mică pe termen lung a dovedit eficiență terapeutică în ceea ce priveşte efectul său antiproteinuric şi renoprotectiv la pacienții cu BCR cauzată de ND, NH sau GN, independent de administrarea de IEC/BRA. Un răspuns terapeutic mai bun a fost înregistrat la pacienții aflați în stadii mai puțin avansate ale disfuncției renale.

Corresponding author: Dr. Diana-Silvia Zilişteanu, Fundeni Clinical Institute, Center of Internal Medicine and Nephrology Romania, Bucharest, Şos. Fundeni nr. 258, sector 2, 022328

Phone +40-744-285843; Fax: +40- 31-8164378

E-mail:diana@nefrolog.ro

\section{REFERENCES}

1. MASOLA V, ZAZA G, GAMBARO G. Sulodexide and glycosaminoglycans in the progression of renal disease. Nephrol Dial Transplant 2014; 29: i74-i79.

2. LAUVER DA, LUCCHESI BR. Sulodexide: a renewed interest in this glycosaminoglycan. Cardiovascular Drug Reviews 2006; 24(3-4): 214-226.

3. LAUVER DA, LUCCHESI BR. Sulodexide: A renewed interest in this glycosaminoglycan. Cardiovascular Drug Reviews 2006; 24(3-4): 214-226. 2

4. MANELLO F, MEDDA V, LIGI D, RAFFETTO JD. Glycosaminoglycan sulodexide inhibition of MMP-9 gelatinase secretion and activity: possible pharmacological role against collagen degradation in vascular chronic diseases. Curr Vasc Pharm 2013; 11: 354-365.

5. BROEKHUIZEN LN, LEMKES BA, MOOIJ HL et al. Effect of sulodexide on endothelial glycocalyx and vascular permeability in patients with type 2 diabetes mellitus. Diabetologia 2010; 53: 2646-2655.

6. KRISTOVA V, LISKOVA S, SOTNIKOVA R et al. Sulodexide improves endothelial dysfunction in streptozotocin-induced diabetes in rats. Physiol Res 2008; 57: 491-494.

7. COFFEY AK, KARNOVSKY MJ. Heparin inhibits mesangial cell proliferation in habu-venom-induced glomerular injury. Am J Pathol 1985; 120: 248-255.

8. LEWIS EJ, XU X. Abnormal glomerular permeability characteristics in diabetic nephropathy: implications for the therapeutic use of low-molecular weight heparin. Diabetes Care 2008; 31(Suppl 2): S202-S207. 
9. CEOL M, GAMBARO G, SAUER U et al. Glycosaminoglycan therapy prevents TGF-betal overexpression and pathologic changes in renal tissue of long term diabetic rats. J Am Soc Nephrol 2000; 11: 2324-2336.

10. MASOLA V, ONISTO M, ZAZA G, LUPO A, GAMBARO G. A new mechanism of action of sulodexide in diabetic nephropathy: inhibits heparanase-1 and prevents FGF-2-induced renal epithelial-mesenchymal transition. $\mathrm{J}$ Translational Medicine 2012; 10: 213.

11. GADDI A, CICERO AFG, GAMBARO G. Nephroprotective action of glycosaminoglycans: why the pharmacological properties of Sulodexide might be reconsidered. Int J Nephrol Renovasc Dis 2010; 3: 99-105.

12. SOLINI A, CARRARO A, BARZON I et al. Therapy with glycosaminoglycans lowers albumin excretion rate in non-insulin dependent diabetic patients with microalbuminuria. Diab Nutr Metab 1994; 7: 304-307.

13. GAMBARO G, KINALSKA I, OKSA A, et al. Oral sulodexide reduces albuminuria in microalbuminuric and macroalbuminuric Type 1 and Type 2 diabetic patients: The Di.N.A.S. randomized trial. J Am Soc Nephrol 2002; 13: $1615-1625$.

14. BLOUZA S, DAKHLI S, ABID H et al. Efficacy of low-dose oral sulodexide in the management of diabetic nephropathy. J Nephrol 2010; 23: 415-424.

15. ROZITA M, MD SHAHRIR MS, LOO CY et al. Glycosaminoglycans (sulodexide) for resistant heavy proteinuria of chronic glomerulonephritides. Nephrology 2008; 13(Suppl 1): A13.

16. BANG K, CHIN HJ, CHAE DW et al. Anti-proteinuric effect of sulodexide in Immunoglobulin A Nephropathy. Yonsei Med J 2011; 52: 588-594.

17. PALATINI P. Glomerular hyperfiltration: a marker of early renal damage in pre-diabetes and pre-hypertension. Nephrol Dial Transplant 2012; 27: 1708-1714.

18. CHRISTIANSEN REF, TENSTAD O, LEH S, IVERSEN BM. Glomerular charge selectivity is impaired in hypertensive nephropathy. Nephrol Dial Transplant, 2004; 19: 1083-1091.

19. HEERSPINK HL, GREENE T, LEWIS JB, et al. Collaborative Study Group. Effects of Sulodexide in patients with type 2 diabetes and persistent albuminuria. Nephrol Dial Transplant 2008; 23(6):1946-1954.

20. LI P, MA LL, XIE RJ, et al. Treatment of 5/6 nephrectomy rats with sulodexide: a novel therapy for chronic renal failure. Acta Pharmacologica Sinica 2012; 33: 644-651. 